\title{
The current state of the ritual folklore of the Altaians (on the material of the fieldwork in 2017)
}

DOI: 10.31551/2410-2725-2019-5-3-323-336

\section{Konunov Arkadiy Alekseevich}

Candidate of Philology Sciences, Senior Researcher, state-financed scientific institution «Scientific research institute of Altaic studies, named after Surazakov, S.S.», Russian Federation, Altai Republic, Gorno-Altaisk. E-mail: konun1974@mail.ru

\begin{abstract}
This work is devoted to the study of the modern state of the ritual folklore of one of the Turkic peoples of Southern Siberia, the Altaians, representing various local ethnic groups. The formation of the vector of ideas about the sacred among the Altaians began in the 90s. Twentieth century. When people again began to venerate sacred objects, partially forgotten during the Soviet era - passes, springs with healing water, to make offerings to the hosts, to pray for murgul during calendar holidays and as a result, sacral rites became open, "legal" and publicly approved. At present, the fixation of a modern ritual material and the preservation of unique verbal patterns and rituals that play a significant role in the life of an ethnic group by creating a folklore collection, then publishing and studying it are caused by the requirements of the time. In addition, in the context of the rapid loss of traditional culture and the natural withdrawal from the lives of experts in the ritual sphere, it is necessary as soon as possible and more fully to fix and study what has survived and reached our days. The components of all the rituals held during calendar holidays for different Altai ethnic groups differ mainly at the level of the text of wishes and some (though also important) external elements of the rite, which is associated with the difference in local traditions. The deep semantics, the direction of the rites and their main stages are identical, which makes it possible to assign all the fixed rites to one common Altai tradition Key words: worldview; tradition; custom; rite; ritual; calendar rite; holiday.
\end{abstract}

\section{Алтайлықтардың әдет-ғұрып фольклорының қазіргі жағдайы (2017 жылғы далалық жұмыстардың материалдары негізінде)}

\section{Конунов Аркадий Алексеевич}

филология ғылымдарының кандидаты, С.С.Суразаков атындағы алтаистика ғылымизерттеу институтының аға ғылыми қызметкері, Ресей Федерациясы, Алтай Республикасы, ГорноАлтайск қ. E-mail: konun1974@mail.ru

Аңдатпа: Бұл жұмыс жергілікті этникалық топтар ретіндегі Оңтүстік Сібірдің түркі халықтарының бірі - алтайлықтардың ғұрыптық фольклорының қазіргі кезеңдегі жағдайын зерттеуге арналған. Алтайлықтардың сакралдылық туралы түсініктерін зерделеу XX ғасырдың 90-жылдарынан бастау алады. Осы кезеңде адамдар кеңестік кезеңде біртіндеп ұмытыла бастаған киелі нысандарды қайтадан насихаттай бастайды. Күнтізбелік мерекелерде асулар, емдік бұлақтарға барып, рух иелеріне құрбандық шалып, мюргюлдік уағыздар жасаудың нәтижесінде сакралды ғұрыптар ашық, "заңды" болып, қоғам қабылдай бастады. Этнос өмірінде маңызды рөл атқаратын бірегей вербалды үлгілер мен қазіргі әдет-ғұрыптық материалдарды сақтау және белгілеу, оларды фольклорлық топтама құру жолымен, кейінірек жариялау және зерттеу уақыт талабына сай болып отыр. Сонымен қатар, дәстүрлі мәдениеттің жедел жойылуы мен әдет ғұрыптық саланы білетін адамдардың азаюы, бүгінгі күнге дейін сақталған ғұрыптарды тез арада және толығырақ зерттеу қажет. Әртүрлі алтайлық этникалық топтардың күнтізбелік мерекелерде жүргізетін барлық рәсімдердің айырмашылығын негізінен сыйыну мәтіндерінің деңгейі мен жергілікті дәстүрлермен байланысты әдет-ғұрыптың сыртқы элементтерінен көруге болады. Әдет-ғұрыптардың түпкі семантикасы, бағыты мен оның негізгі кезеңдері бірдей болып келеді. Сондықтан, барлық белгілеген әдет-ғұрыптарды бір ортақ алтай дәстүріне жатқызуға болады. Түйін сөздер: дүниетаным; дәстүр; әдет-ғұрып; рәсім; ритуал; күнтізбелік рәсім; мереке.

\section{Современное состояние обрядового фольклора алтайцев (на материале полевых работ 2017 г.)}

\section{Конунов Аркадий Алексеевич}

кандидат фрилологических наук, старший научный сотрудник, Бюджетное научное учреждение Республики Алтай «Научно-исследовательский институт алтаистики им. С.С. Суразакова, Российская Федерация, Республика Алтай, Горно-Алтайск. E-mail:konun1974@mail.ru 
Аннотация: Данная работа посвящена изучению современного состояния обрядового фольклора одного из тюркских народов Южной Сибири алтайцев, представляющих различные локальные этнические группы. Формирование вектора представлений о сакральном у алтайцев началось в 90-х гг. XX в. когда люди вновь стали почитать сакральные объекты, частично забытые в советское время - перевалы, источники с целебной водой, совершать подношения духам-хозяевам, совершать моления мюргюл во время календарных праздников и в следствии сакральные обряды стали открытыми, «легальными» и общественно одобряемыми. В настоящее время фиксация современного обрядового материала и сохранение уникальных вербальных образцов и обрядов, играющих значительную роль в жизни этноса, путём создания фольклорной коллекции, последующей её публикации и изучение вызваны требованиями времени. Кроме этого в условиях стремительной утраты традиционной культуры и естественного ухода из жизни знатоков обрядовой сферы необходимо как можно скорее и полнее зафиксировать и изучить то, что ещё сохранилось и дошло до наших дней. Составляющие всех обрядов, проводимых во время календарных праздников у разных алтайских этнических групп, различаются в основном на уровне текста благопожеланий и некоторых (впрочем, тоже важных) внешних элементов обряда, что связано с различием локальных традиций. Глубинная же семантика, направленность обрядов и основные их этапы идентичны, что позволяет отнести все зафиксированные обряды к одной общей алтайской традиции.

Ключевые слова: мировоззрение; традиция; обычай; обряд; ритуал; календарный обряд; праздник.

\section{УДК/UDC 398.3}

\section{Современное состояние обрядового фольклора алтайцев (на материале полевых работ 2017 г.)}

\section{А.А. Конунов}

Введение. За время своего длительного развития алтайцы создали богатейшую духовную культуру, в которой фольклор составляет наиболее её традиционную часть. Фольклор - это вид коллективного устного народного поэтического творчества, имеющий полифункциональную природу, в которой органически взаимодействуют слово - музыка - действие. Особенно ярко этот комплекс проявляется в обрядовом фольклоре, в котором получили полноценное бытование разные жанры, такие как: культовая, календарная, трудовая обрядность, куда включаются промысловые, скотоводческие, земледельческие обряды, семейная обрядность, состоящая из обрядов жизненного цикла (рождение, свадьба, похороны), обрядовый фольклор окказиональной природы (заговоры, заклинания, заклички). Традиционная народная обрядность в процессе своего развития накапливала разнообразный опыт многих поколений. Обряды имели ритуально-магическое значение, регламентировали поведение человека в быту и труде, содержали правила взаимодействия с окружающей природой, определяя экологическое к ней отношение, помогали в освоении трудовых навыков.

Материалы и методы. Несмотря на это, обрядовый фольклор мало изучен в силу сложившихся в советское время идеологических установок, связанных с религией и традиционными верованиями, вследствие сложности самого обрядового комплекса, а также в связи с архаическими проявлениями в обрядах, трудно поддающемуся пониманию. Многое в обрядовой поэзии остается невыясненным и спорным, требующим дополнительного изучения. В отечественной фольклористике нет специальных работ, посвященных обрядовому фрольклору алтайцев. Также незначительно число научных изданий с текстами обрядовой поэзии. 
Все это объясняет тот факт, что сбор, научное осмысление, изучение и анализ самих обрядов, а также обрядовой поэзии выдвигается в ряд наиболее актуальных проблем алтайской фольклористики.

Статья основана на полевых материалах (видео-, фоото-материалы двух праздников Чага байрам, двух праздников Дьылгайак, трех праздников Дьажылбюр - «Зеленая листва» и двух - Сары бюр - «Желтая листва»), собранных в 2017 г. научными сотрудниками НИИ алтаистики им. С.С. Суразакова и Института фрилологии СО РАН Конуновым А.А. и Сагалаевым К.А. Целью сбора полевых материалов являлась комплексная запись всего годового цикла алтайских обрядовых праздников.

Результаты. Календарная обрядность занимает особое место в духовной культуре каждого этноса: она символически подтверждает прочность, незыблемость окружающего мира и места человека в нем. Заключая с природой, своей землей очередной «договор», люди хотят быть уверенными: после долгой зимы вовремя придет весна, а вслед за ней и лето; будет хороший приплод скота и урожай, здоровье, достаток и мир. Именно для этого, со строгим соблюдением правил, и проводятся календарные обряды. Они вносят прерывность и цикличность в течение времени, служат периодическому обновлению переживания времени. Символика временной границы, смены старого новым, смерти - жизнью сближает календарные обряды с переходными обрядами (отсюда - обычай праздничной уборки в доме, обновления огня в очаге, одежды и т.п.) (БРЭ, 2008: 490). Отражая мировоззрение, прежде всего конкретного этноса, календарно-обрядовый фольклор, тем не менее, всегда существует в контексте его этнокультурных контактов: «как концентрированное выражение материальной и духовной культуры народов, календарные праздники несут на себе печать этнической специфики. В то же время они отражают типологическую общность человеческой культуры, влияние историко-культурных контактов и связей» (Модель, 1985: 3).

Многие традиционные праздники алтайцев имеют календарный характер, т.е. ритуалы «Белый праздник» (Чага байрам), Новый год (Дьылгайак), праздники Зеленой (Дьажылбюр) и Желтой листвы (Сары бюр) функционально связаны с переходными циклами между холодным и теплым периодами года, наступлением нового сезона, связанного с бытовой жизнью народа. В мировоззрении алтайского народа природа защищает человека $и$ покровительствует ему. Алтайцы всегда соблюдали тюркский солнечно-лунный календарь; все праздники и моления проводили и до сих пор проводят в новолуние.

Как известно, с конца XVI в. буддизм получил официальный статус религии в Джунгарском ханстве, куда с XVII в. Саяно-Алтай вошёл в качестве конфедеративных союзников ойротов. Там он сосуществовал с местными религиозными верованиями: архаическими культами, шаманизмом, образуя причудливые сочетания с указанными культами.

Из тех времен у алтайцев сохранился праздник Чага байрам - «Праздник белого месяца» (букв. 'Белый праздник'). Он празднуется по лунному календарю (конец января - начало фревраля) вместе с монголами, тувинцами, бурятами, калмыками, народами Тибета и Индии.

В Республике Алтай Чага байрам как праздник календарной обрядности с конца XX по первые десятилетия XXI вв. прошел своего рода путь возрождения в статусном плане от семейно-родового праздника до государственного и в ритуальном плане от сочетания на первый взгляд ряда 
самостоятельных обрядов и ритуалов до единой сакральной системы календарной обрядности.

Коллективное празднование Чага байрам началось в 90-е гг. XX в. Праздник начинается ранним утром, когда старейшины совершают обряды поклонения силам природы, Алтаю. После их исполнения начинаются культурные и спортивные мероприятия национального характера. Чага байрам является примером связи алтайцев с тюрко-монгольским миром, в силу геополитического положения Алтая и культурного родства между народами Центральной Азии.

В начале феевраля 2017 г. в окрестностях сёл Мухор-Тархата в местности Шын-Бажы (2-го февраля) и Теленгит-Сортогой в животноводческой стоянке Шаараш (5-го февраля) Кош-Агачского района участниками проекта удалось зафиксировать на видео-, фото- и аудиоаппаратуру два обряда молений санг, проводимых во время Чага байрам.

В первом случае моления носили коллективный характер, где в основном участвовали жители с. Мухор-Тархата Кош-Агачского района Республики Алтай из разных родов, разного возраста и пола. Относительно места проведения Чага байрам на сегодняшний день основными требованиями выступают ритуальная чистота местности. Для людей, посещающих эти места, в том числе и вне обрядового времени / действия, существует комплекс запретов и ограничений, основная суть которых сводится к уважительному и бережному отношению к сакральным объектам. Например, близ священных мест и непосредственно на священных объектах нельзя веселиться, шуметь, сквернословить, справлять нужду, женщинам запрещается подниматься на эти местности с непокрытой головой, открытыми руками, плечами, без обуви, считается, что нарушение этих запретов чревато такими последствиями как несчастия, болезни, «убыль» в семье нарушителя.

Следующим важным этапом в организации Чага байрам является подготовка к обрядам и ритуалам праздника. В первую очередь, необходимо подготовить свое жилище к встрече Чага байрам. Вторым важным компонентом является чистая, опрятная и красивая традиционная одежда, именуемая в народе как кеп-кийим. Третий компонент - ритуальная пища, посуда, таган и необходимая утварь для организации ритуального пространства. При проведении ритуалов используют свежее, еще никем не испитое молоко. В качестве подношений используется целый спектр производных продуктов из молока: кислый сыр курут, пресный сыр быштак, топленое масло сардьу и др.

Мясное подношение обычно состоит из мяса барана, но преподносятся только лучшие, сакрально чистые части туши и внутренностей: грудина тёш, кусочки сердца дюрек, оконечная часть хвоста куйрук, колеблющиеся ребра сюмека быргалар. Обязательными условиями подношений является парность ритуальной пищи и отсутствие соли в продуктах.

Злаковые продукты представлены лепешками тертпек, жареными пончиками боорсок, жаренными и измельченными в зернотерке баспак зернами ячменя талкан.

По завершению подготовительных мероприятий в назначенный день проводятся собственно обряды и ритуалы Чага байрам. Обряд сангсалар включает в себя множество ритуалов, состоящих в возжигании ритуального огня, подвязывании ритуальных лент дьалама, поклонении огню От-Эне, коллективном молении мюргюл.

Прошедший 2 февраля 2017 г. Чага байрам в местности Шын-Бажы близ с. Мухор-Тархата Кош-Агачского района Республики Алтай, начался со встречи 
участников у подножия горы, на котором расположен жертвенник тагыл. Ритуальные действия начинаются только после того как взойдет солнце. Считается, что с восходом солнца наступивший новый год встречает Хозяин Алтая - Алтайдынгээзи.

После того как соберется достаточное количество людей начинается шествие к тагыл`у, вначале идут мужчины во главе «знающего человека» неме билер кижи, который будет проводить собственно обряды, за ними идут женщины, дети. По пришествию к тагылуу рядом с ним расстилается войлочный ковер, на который выкладывают принесенные продукты, также кладут можжевельник, который своим присутствием освящает все принесенные продукты, напитки.

Во время подготовки ковра и раскладки продуктов, мужчины разжигают огонь. После начинается подготовка ритуальных лент дьалама, в основном белого цвета. Первым повязывает дьалама неме билер кижи, потом остальные участники, во время подвязывания люди просят благословления, здоровья и благополучия себе и своим близким. Повязав дьалама, все участники рассаживаются лицом к востоку вокруг тагыла, расположение участников строго согласно канону, как в юрте с левой стороны садятся мужчины, с правой - женщины. Начинаются собственно моления мюргюл.

Распорядитель неме билер кижи начинает моление с обращения духу огня От-Эне, сопровождая молитвы кормлением молоком и возжиганием можжевельника, в ходе молитв он совместно с помощником преподносит духу огня принесенные продукты, сжигая их в огне. Моления продолжаются восхвалением Алтая, неме билер кижи обращается к Хозяину Алтая, перечисляет все сакральные горы Алтая, священные местности и горные массивы, перевалы, прося здоровья народу, плодородия для скота, постоянства мирозданию, о миновании стороной бед и несчастий. Моления сопровождаются кроплением молока сторонам света, в текстах благопожеланий он обращается к наступающему новому году, прося достатка в семьях, плодородия земли, хорошего урожая, мягкой зимы и теплого лета. Вслед за ним все присутствующие поклоняются восходящему солнцу и духу огня От-Эне, проговаривая молитвы, прошения про себя или чуть слышно с упоминанием своего имени и рода.

По завершению молитв-прошений, проводимых неме билер кижи, присутствующие сами производят кормление огня молоком, сопровождая кропления благопожеланиями. Участники молений по завершению ритуальной части также должны присесть у праздничного ковра и отведать принесенные угощения.

Заканчивается обрядовая часть Чага байрам ритуалом јерге анданар, скатывания с горы методом перекатов. Считается, что вовремя перекатывания человек вбирает в себя силу земли, нового года и привлекает благодать, удачу, а снег очищает тело и одежду от скверны.

Во втором случае Чага байрам носил семейный характер. В отличие от коллективного, здесь обряды и ритуалы Чага байрам проводились во дворе дома (животноводческой стоянки). С восходом солнца вся семья собирается вокруг тагыл`а (вертикально поставленное бревно высотой 1 м, сверху которого кладется плоский камень диаметром 40-50 см.) Хозяин дома - глава семьи разводит огонь на камне и далее начинает окуривать огонь можжевельником, кропя молоком, чаем с молоком во все четыре стороны света по движению солнца, произносит благопожелания родовым горам, солнцу, Алтаю. После этого он преподносит огню угощения из определенных частей сваренной туши барана, кислый сыр курут, пресный сыр быштак, 
топленое масло сардьу, лепешки и др. Таким образом, люди благодарили Хозяина Алтая за благополучную зимовку.

По завершению благопожеланий и испрашиваний, проводимых главой семьи, остальные члены семьи сами произвели кормление огня молоком, сопровождая кропления благопожеланиями. Далее глава семьи преподносит угощения огню в доме (в данном случае огонь в печке), сопровождая благопожеланиями. Все члены семьи и гости по завершению ритуальной части садятся за праздничный стол отведать угощения. Среди празднующих царит веселая, непринужденная обстановка, поют народные песни.

Дьылгайак как календарный праздник - приход весны и Нового года сложился на базе архаичных народных традиций. По словам алтайского сказителя, знатока устного народного творчества алтайцев Н.К. Ялатова, в старину алтайский народ во время праздника Дьылгайак с благословением встречал [Новый год], праздновал, провожал зиму. Помнится, мне, что я этот праздник видел в 1930 г. Дьылгайак празднуется в первый день полнолуния месяца тулаан (март).

Название этого праздника можно интерпретировать как «Праздник катания»: от слов дьыл 'ползи', дьынгыла 'катайся', дьылгай 'пусть ползет'. В этот день было принято кататься с гор на шкурах, палками колотили снег, чтобы он скорей растаял, и быстрее наступила весна, пришло тепло.

В марте 2017 г. нам удалось зафиксировать на видео и фотоаппаратуру два праздника Дьылгайак: в окрестностях с. Каракол Онгудайского района и в с. Красносельск Чойского района Республики Алтай.

В местности Бай-Туу в окрестностях с. Каракол Онгудайского района моление мюргюл во время праздника Дьылгайак состоялось 6 марта 2017 г. в восьмой день новолуния. Моление мюргюл проводился по следующей схеме:

К проведению обряда готовятся заранее - собирают молоко, готовят пресный сыр быштак, из которого вырезают шатра (это маленькие фригурки священной (родовой) горы, айыла, очага, домашней утвари, коновязи, коня, овец, хозяев айыла и т.д.), овцу белой масти закалывают за день до праздника, утром в день обряда идут за родниковой водой.

В день обряда рано утром, в 6 часов, несколько мужчин поднимаются к месту оду (букв. 'стан, становище') перед жертвенником или алтарем, сооруженным из камней тагыл, разводят огонь и варят тушу барана без соли. Ближе к восходу солнца к месту оду перед тагылом собираются остальные участники обряда (мужчины, женщины, дети) и начинают готовиться к молению. Прямо на месте готовят ленточки дьалама из четырех цветов попарно: белый, желтый, зеленый, синий (голубой). Далее все участники обряда очищаются (умывают руки и лицо) родниковой водой и идут наверх к тагылу. Перед ритуалом завязывания ленточек мужчины и женщины, участники обряда, садятся отдельно друг от друга. Первыми повязывать дьалама идет человек, который проводит моления, произносит благопожелания, в данном случае Яманчинов Яков Сергеевич из рода тёлёс (1972 г.р.), далее алкышчы, и его помощник шабычы. После их возвращения идут остальные мужчины, после мужчин - женщины. Ленточки привязывают попарно, по цветам (белый, желтый, зеленый, синий (голубой), слева направо.

После завязывания ритуальных ленточек участники обряда идут к тагылам. Их десять: центральный тагыл посвящен местной священной горе Бай-Туу, которая располагается у с. Каракол, остальные расположены с востока по движению солнца вокруг центрального тагыла, начиная с горы Белуха (Кадын Бажы Юч-Ыйык); далее поочередно идут остальные священные горы Алтая. На каждом из них помощник шабычы разводит огонь. 
После того, как алкышчы заканчивает ритуал моления (окропление молоком, произнесение оригинальных благопожеланий) каждому из тагылов и шесту сюме-чакы (на шесте сюме-чакы располагаются фрлаги (маанылар) белого, голубого, жёлтого и зелёного цветов из ситца, их размеры - 1 метр в ширину и 1,5 метра в длину; на верхушке шеста находится деревянная фригурка тотемной птицы горы Бай-Туу - белая куропатка агуна), все, в том числе женщины и дети, обходят ритуальное сооружение по кругу, касаясь руками каждого тагыла. На обряде обязательно присутствуют ясновидящий (кёспёкчи), который в ходе молений видит невидимое, и человек, которого называют неме билер кижи (букв. знающий человек), который слышит божественное откровение или предзнаменование чего-либо, неслышимое для остальных.

Следующее ритуальное действие - это расстановка шатра на тагылах: девушки ставят на коврик ширдек (коврик из белого войлока с рисунками, символизирующими природу Алтая, окружающее пространство) фригурки шатра, и одна из девушек несет их к тазыл'ам. Алкышчы, ставит их по очереди на каждый тагыл.

Далее алкышчы окуривает можжевельником каждый тагыл, затем идет к коновязи, окуривает её и произносит благопожелания (коновязь в данном случае является коновязью Хозяина Алтая).

После этого алкышчы кропит молоком в небо перед главным тагыл ом, говорит благопожелание, затем делает то же перед остальными тагыл ами и окропляет молоком коновязь. За этим следует угощение огня, т.е. духов хозяев священных гор: на тагыл ы кладутся мясо (куски грудинки, сердца и кусочки мякоти без костей, сваренные без соли), пресный хлеб, талкан, топленое масло, льется из ритуальной деревянной ложки мясной бульон, мясной суп с перловкой кёчё. Далее все участники молений по очереди угощают огонь на

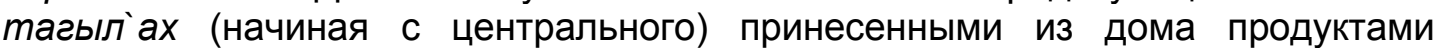
собственного приготовления (мясо, молочные продукты, талкан, топленое масло), и несколько минут все про себя молятся, кланяясь тагыл ам. После молений на месте сбора оду всеми участниками обряда устраивается трапеза (едят мясо, остатки продуктов принесенных из дома для молений, мясной суп с перловкой кёчё), во время которой ясновидящий (кёспёкчи) и неме билер кижи делятся «увиденным» и «услышанным» с остальными.

В с. Красносельск Чойского района праздник Дьылгайак состоялся 12 марта 2017 г.

Праздник был запланирован как Дьылгайак районного уровня, на мероприятие съехались представители из семи поселений, это села Каракокша, Паспаул, Сейка, Уймень, Чоя, Ынырга.

Обрядовую часть праздника проводила Зинаида Танышевна Тырысова из рода кёбёк, усеченная часть обряда Восхваления Алтая, усеченность эксперт объяснила, тем, что «Алтайдынг кулагы ачылбан» (досл. Ухо Алтая еще не открылась, подр. Хозяин Алтая еще не проснулся для обрядов).

Обрядов календарного цикла с исполнением ритуалов и отправлением культов зафиксировать не удалось. В большей степени мероприятие было реализовано как эстрадно-досуговое, творческих коллективов Чойского района.

С давних времен алтайцы проводят весенне-осенние моления духамхозяевам родовых гор и Алтая, направленные на испрашивание плодородия, изобилия, приумножения скота. Это моления Дьажылбюр на первое новолуние в июне, ближе к летнему солнцестоянию, и в сентябре - Сары бюр, ближе к осеннему солнцестоянию.

В местности Бай-Туу в окрестностях с. Каракол Онгудайского района обряд поклонения Алтаю во время зеленой листвы Дьажылбюр состоялся 
3 мая 2017 г. (в восьмой день новолуния). В Кош-Агачском районе в окрестностях с. Ортолык этот же праздник прошел 2 июня 2017 г., тоже в восьмой день новолуния (по календарю - девятый день новолуния, однако старейшины, проводившие обряд, считают по-другому). В Улаганском районе, в окрестностях с. Чибиля, Дьажылбюр был проведен 3 июня 2017 г., в десятый день новолуния.

На наш вопрос: «Почему в долине Каракола обряд проводится в мае, а в Кош-Агачском и Улаганском районах в начале июня?» проводивший ритуал С.Я. Яманчинов ответил: «Обряд должен проводиться в мае (в месяце кукушки) после первого голоса кукушки и первых ростков зеленой травы (кёк). Алтаец с древних времен связан с природой, и он должен понимать, что природа диктует нам свои условия, а не мы. $И$ человек своими благопожеланиями сможет поддержать природу, окроплением молока и угощениями сможет смягчить Хозяина Алтая. Мы просим у хозяев священных гор Алтая, чтобы весна не затянулась, чтобы природа быстрее ожила, и позеленел Алтай...».

В Кош-Агачском и Улаганском районах причину проведения обряда в июне объяснили природно-климатическими условиями данных районов. Эти суровые условия явились основанием для официального причисления их к районам Севера.

Участие в таких молениях имеет и свои ритуальные правила (запреты). К примеру, запрещается идти на моления тем, у кого умер кто-либо из близких родственников, а также людям, участвовавшим в похоронах - в противном случае можно привести на священное место молений скверну. Такой запрет, если умер родной человек, длится целый год. Запрет на участие в обряде касается также тех женщин, у которых период естественного недомогания.

На молениях люди должны себя вести тихо: нельзя кричать, смеяться, громко разговаривать, ссориться и ругаться, так как все это считается неприятным для духов Алтая.

В Караколе моление мюргюл во время обряда Дьажылбюр проводится по следующей схеме:

К проведению обряда готовятся за три дня - собирают молоко, готовят пресный сырбыштак, из которого вырезают шатра (маленькие фригурки священной (родовой) горы, айыла, очага, домашней утвари, коновязи, коня, овец, хозяев айыла и т.д.), овцу белой масти режут за день до праздника, утром в день обряда идут за родниковой водой.

В день обряда рано утром, в 6 часов, несколько мужчин поднимаются к месту оду (букв. 'стан, становище') перед жертвенником или алтарем, сооруженным из камней тагыл, разводят огонь и варят тушу барана без соли (все продукты обряда должны быть без соли, так как преподносить соленые, спиртные ачуаш угощения хозяевам священных гор Алтая запрещается). Ближе к восходу солнца к месту оду перед тагыл ом собираются остальные участники обряда (мужчины, женщины, дети) и начинают готовиться к молению. Прямо на месте готовят ленточки дьалама из четырех цветов попарно: белый, желтый, зеленый, синий (голубой). По словам алкышчы Яманчинова Якова Сергеевича из рода тёлёс, 1972 г.р., который проводит все обряды годового цикла в местности Бай-Туу, ленточки белого цвета посвящаются «белому-ясному» ак-айас, т.е. невидимому воздуху, которым мы дышим, желтого цвета - священным горам, перевалам Алтая, зеленого цвета всему живому (в первую очередь имеется в виду растительность), диким и домашним животным и людям, синего (голубого) цвета - «синему-ясному» $\kappa$ ёк-айас, небожителям, космосу, а также к рекам, озерам, родникам Алтая. 
Далее все участники обряда очищаются (умывают руки и лицо) родниковой водой и идут наверх к тагылу. Перед ритуалом завязывания ленточек мужчины и женщины участники садятся отдельно друг от друга, молятся про себя. Первыми повязывать дьалама идут человек, который проводит моления, произносит благопожелания алкышчы, и его помощник (шабычы), который в процессе моления разводит огонь в тагылах, наливает молоко и мясной бульон с зернами ячменя или пшеницы (мясной суп с перловкой кёчё) в ритуальную чашу, с которой алкышчы совершает ритуальное окропление духам-хозяевам священных гор, Алтая. После их возвращения идут остальные мужчины, после мужчин - женщины. Ленточки привязывают попарно, по цветам (белый, желтый, зеленый, синий (голубой), по движению солнца.

Когда привязывают пару ленточек, то верхний конец одной ленточки на 1-2 см должен быть выше другого. По словам участников обряда, это символизирует, что человек, завязывающий ленточки, ставит свою светлую сторону выше, чем темную.

После завязывания ритуальных ленточек участники обряда идут к тагылам. Их десять: центральный тагыл посвящен местной священной горе Бай-Туу, которая располагается у с. Каракол, остальные расположены с востока по движению солнца вокруг центрального тагыла, начиная с горы Белуха (Кадын Бажы Юч-Ыйык); далее поочередно идут остальные священные горы Алтая: 3) Каракол Бажы Юч-Сӱмер, 4) Бабырган, 5) Чаптыган, 6) Эдье-Кан, 7) Аба-Кан, 8) Каракол БажыЈал-Монкӱ, 9) Кёкёрю Бажы Кёк-Мёнкю, 10) Ак-Алака (на всех тагылах сверху лежат плоские камни, специально привезенные с той горы, которой посвящен тагыл). На каждом из них помощник шабычы разводит огонь. Кроме дров из лиственницы, в каждый кладут пару веточек можжевельника артыш, арчын. После того, как алкышчы заканчивает ритуал моления (окропление молоком, произнесение оригинальных благопожеланий каждому из тагылов и шесту сюме-чакы (на шесте сюме-чакы располагаются фрлаги маанылар белого, голубого, жёлтого и зелёного цветов из ситца, их размеры - 1 метр в ширину и 1,5 метра в длину; на верхушке шеста находится деревянная фригурка тотемной птицы горы Бай-Туу белая куропатка агуна), все, в том числе женщины и дети, обходят ритуальное сооружение по кругу, касаясь руками каждого тагыла. На обряде обязательно присутствуют ясновидящий кёспёкчи, который в ходе молений видит невидимое, и человек, которого называют неме билер кижи (букв. 'знающий человек'), который слышит божественное откровение или предзнаменование чего-либо, неслышимое для остальных.

Следующее ритуальное действие - это расстановка шатра на тагылах: девушки ставят на коврик ширдек (коврик из белого войлока с рисунками, символизирующими природу Алтая, окружающее пространство) фригурки шатра и одна из девушек несет их к тагылам. Алкышчы ставит их по очереди на каждый тагыл. По словам Д.В. Арзютова, «изготовляемые из сыра (быштак) шатра представляют собой воплощение алтайской концепции дьурт как хозяйства, семьи, дома, дополненных символом священной горы. Шатра - это набор парных элементов: мужчина и женщина, пары домашних животных, а также модели оснований айыла в виде шести вырезанных из сыра небольших столбиков, моделей внутреннего убранства и т.п. Исключительно непарными элементами шатра выступают коновязь (чакы) и священная гора для Каракольской долины - Юч-Энмек» (Арзютов, 2014: 118-119).

Во время расстановки шатра одновременно женщины поют песни дьангар, восхваляющие Алтай, мужчина играет на топшуре, аккомпанируя им. После песен он горловым пением исполняет благопожелания священным 
горам Алтая. Далее алкышчы окуривает можжевельником каждый тагыл, затем идет к коновязи, окуривает её и произносит благопожелания (коновязь в данном случае является коновязью духа-хозяина Алтая).

После этого алкышчы кропит молоком в небо перед главным тагылом, говорит благопожелание, затем делает то же перед остальными тагылами и окропляет молоком коновязь. За этим следует угощение огня, т.е. духов хозяев священных гор: на тацылы кладутся мясо (куски грудинки, сердца и кусочки мякоти без костей, сваренные без соли), пресный хлеб, талкан, топленое масло, льется из ритуальной деревянной ложки мясной суп с перловкой кёчё. Далее все участники молений по очереди угощают огонь на тагылах (начиная с центрального) принесенными из дома продуктами собственного приготовления (мясо, молочные продукты, талкан, топленое масло), и несколько минут все про себя молятся, кланяясь тагылам. После молений на месте сбора оду всеми участниками обряда устраивается трапеза (едят мясо, остатки продуктов, принесенных из дома для молений, мясной суп с перловкой кёчё), во время которой ясновидящий кёспёкчи и неме билер кижи делятся «увиденным» и «услышанным» с остальными.

Жители Кош-Агачского района массовые моления проводят вблизи с. Ортолык, где установлено крупное ритуальное сооружение сане-таш (букв. 'камень-жертвенник'). Он состоит из 13 тагылов: центральный тагыл, вокруг которого расположены ещё 12 тагылов в строгой последовательности согласно алтайскому календарю 12-летнего животного цикла. Рядом с тагылами расположено каменное сооружение обоо, поставлены два шеста (чакы), между которыми протянута ритуальная веревка дьибек, свитая из белых конских волос или белой овечьей шерсти для привязывания жертвенных ленточек дьалама. Также в некотором отдалении от тагылов стоит шестиугольный деревянный айыл (раньше на место моления привозили и ставили войлочные юрты). Между айылом и тагылами стоят каменные изваяния.

В Кош-Агачском районе моления мюргюл во время праздника Дьажылбюр проводится по следующей схеме:

К проведению обряда готовятся заранее - собирают молоко, айрак, кумыс, шубат - кисломолочные напитки из коровьего, кобыльего и верблюжьего молока, аракы - спиртной напиток, выгнанный из вышеназванных кисломолочных напитков. За день до праздника закалывают овцу белой масти.

С восходом солнца в 7.30-8.00 часов участники молений собираются и идут к обоо класть камни и повязывать ленты-дьалама (в основном белого цвета, хотя встречаются и ленты синего, зеленого и красного цветов). В айыле разводят огонь, варят баранину и готовятся к молениям (готовят ритуальные ленточки, угощение на большом деревянном блюде тепши для духов Алтая, куда кладут куски грудинки, сердца и кусочки мякоти без костей, сваренные без соли, пресный сыр быштак, талкан, топленое масло).

Далее все вместе идут к двум столбам, тоже повязывают ритуальные ленточки-дьалама. В отличие от описанного ранее обряда, мужчины и женщины привязывают дьалама одновременно.

После привязывания дьалама участники молений идут к тагылам и садятся полукругом лицом к солнцу (к востоку): если смотреть со спины, то женщины слева, мужчины - справа. На центральном (главном) тагыле помощник зайсана разводит огонь (в Кош-Агачском районе роль алкышчы исполняет главный зайсан (Ага дьайзанг) Юрий (Ботпок) Курманович Топошев из рода тёлёс), далее алкышчы возжигает можжевельник, окуривает тагыл и остаток можжевельника кладет в огонь, потом туда же кладет угощение с 
тепши. Далее он сначала кропит молоком из ритуальной деревянной чашки деревянной ложкой в огонь и на все четыре стороны света, обходя главный тагыл по движению солнца, и произносит благопожелания духам-хозяевам гор, Алтая, потом кропит кисломолочными напитками. Чашку постоянно наполняют остальные участники молений, в основном помощник. После ритуала окропления остатки молока и кисломолочных напитков по кругу дают отведать присутствующим. Далее все участники молений по очереди обходят круг, кладут на центральный тагылк то, что принес из дома, кропят молоком в четыре стороны света и на тагылы, обходят тагыл по кругу. Под конец молений все участники молений, взявшись за руки, идут вокруг тагылов хороводом с возгласами «Куруй, Куруй!». По словам В.И. Вербицкого, во время кровавого жертвоприношения кам (шаман), «когда лошадь долго бьется, берет чашку и, поднося к издыхающей лошади, произносит: «куруйлапјат, куруйлапдьат, оп куруй, оп куруй, оп куруй». Это значит: буду ловить счастье, или остальную силу, выходящую с жизнью, на приплод» (Вербицкий, 1893: 69). В современных обрядах без кровавого жертвоприношения, по словам информантов, куруй - это испрашивание у Хозяина Алтая счастья, благополучия для людей, приплода, умножения домашнего скота. После этого ритуала участники молений кланяются тагылам и уходят в айыл. По пути к айылуалкышчы кропит молоком каменные изваяния.

В айыле совершается ритуал кормления огня. Огонь окропляют молоком, кладут можжевельник, талкан, топленое масло, лепёшки. Произносится благопожелание огню.

В Улаганском районе место проведения обрядов находится на склоне горы, напротив с. Чибиля. По сравнению двумя другими праздниками, на данном обряде присутствовало гораздо меньше участников - около пятнадцати человек, и сам ритуал занял менее продолжительное время. Впрочем, структура его в целом соответствует описанным выше обрядам:

Утром участники собираются на месте проведения обряда, приносят с собой угощения для духов-хозяев священных гор: молоко и кисломолочные продукты, талкан, хлеб. Разжигается огонь, от кусков ткани отрывают ленточки дьалама (на данном обряде все ленточки были белого цвета), готовые ленточки очищают дымом костра. Алкышчы, аккомпанируя себе на топшуре, исполняет горловым пением благопожелания священным горам Алтая.

Алкышчы очищает всех участников обряда специально принесенной родниковой водой (умывают руки и лицо сначала мужчины, следом за ними женщины). В том же порядке (мужчины - первые) поднимаются к месту, где между столбом и растущей здесь лиственницей повязаны дьалама. Каждый повязывает свою ленточку, молча, произнося благопожелания про себя.

После этого все поднимаются еще выше по склону горы - туда, где устроен тагыл. Последний представляет собой сложенный из плоских камней жертвенник круглой формы, около 4 м в диаметре, напротив которого врыты в землю три коновязи чакы. Шабычы (помощник) разводит огонь, после чего алкышчы кладет в него угощения духам Алтая - можжевельник артыш, хлеб, талкан, топленое масло. После него такое же угощение подносят духам присутствующие на обряде мужчины, за ними - женщины.

Алкышчы кропит молоком по сторонам света и в небо перед тагылом, произнося благопожелание, затем под аккомпанемент топшура опять исполняет благопожелания горловым пением. После этого зажженным можжевельником он окуривает окружающее пространство, что и является фрактическим завершением ритуала. Все спускаются вниз и участвуют в общей 
трапезе участников праздника. Легко заметить, например, что в данном случае не проводилось окуривание и окропление молоком коновязей (которых в одном из предыдущих обрядов не было совсем), отсутствовали и каменные изваяния кезер-таш.

В местности Алтын Туу вблизи с. Экинур Усть-Канского района моление мюргюл во время Желтой листвы Сары бюр состоялось 27 сентября 2017 г.

Этот календарный обряд поклонения Алтаю проводится осенью, в сентябре-октябре, в период новолуния, когда природа переходит в умиротворенное состояние, лиственный лес покрывается позолотой, земля еще не промерзла, а люди готовятся к зиме. По сообщению информантов, Эчиша Тоедова, Алега Казакулова, Валерия Делдошпоева к этому обряду раньше готовились задолго. Здесь одним из главных актов является отбор коня, которого предстоит преподнести в дар Хозяину Алтая, причем коня необъезженного любой масти, кроме вороного, но с белой отметиной на лбу. В гриву коня вплетают две ритуальных ленточки дьалама и после совершения обряда пускают в табун.

Дня за четыре до проведения обряда люди соблюдают различного рода запреты: нельзя копать землю, закалывать животного, выносить из дома молоко и т.п. Готовят пищу для обряда: молоко, желательно от коровы рыжей масти и с целыми рогами; или кумыс из молока кобылицы светлой масти, традиционные молочные продукты, испеченная в золе лепешка теертпек, талкан и др.

Во время обряда главным исполнителем был алкышчы Делдошпоев Валерий Кымович из рода очы, 1969 г.р., а также алкышчы Тоедов Ечиш Некорович из рода очы, 1933 г.р. и кам Казакулов Алег из рода ара-тодош, 1942 г.р. Заметим, что представленный материал в значительной степени фриксирует возрождение этого обряда, многое можно воспринять как всплеск памяти традиции, но он хорош для анализа динамики обряда во времени.

Место проведение обряда находилось в 8 км. от с. Экинур Усть-Канского района на открытом склоне с юго-восточной стороны горы Алтын Туу (букв. 'Золотая гора'), покрытой лиственничным лесом. Здесь находилось прямоугольной фрормы сооружение из камней в виде обоо, высотой 1,5 м., длиной около 8 м. шириной около 2 м. Это - главный тагыл. Ечиш Тоедов назвал его «Золотой стол Хозяина Алтая». На юго-восточной стороне центрального тагыла чуть в отдалении (1,5-2 м.), находились еще восемь тагылов сложенных из плоских камней. На восточной стороне от главного тагыла стоят две коновязи Высотой до 2-х м. между ними длинный шест, к верхушке которого привязана белая ткань примерно 1 на 1 метр.

Внизу на поляне находится оду (букв. 'стан, становище'), где разводится огонь. После этого молоком алкышчы начинает окроплять огонь и таким образом приступает к ритуалу благословения огня. Далее возжигает от огня ветку можжевельника и два раза по кругу начинает окуривать себя, посуду, пищу, костер и участников молений. Таким образом, алкышчы очищает участников обряда перед тем, как идти к тагылу. После этого, двое мужчин остаются в стане, на огонь ставят казан, в котором варят тушу барана.

Остальные участники молений, поднявшись к тагылу, рассаживаются с северо-западной стороны главного тагыл'а, расположение участников строго согласно канону, как в айыле с левой стороны садятся мужчины, с правой женщины. Начинаются собственно моления мюргюл.

Помощники алкышчы разводят огонь на двух местах на главном тагыле, потом на остальных восьми тагылах. Далее ковер для сидения ширдек для Хозяина Алтая (окуривают) проводят над пламенем и несут еще выше к юго- 
западу от тагылов (около 30 м.) и там расстилают. Перед ширдеком расстилают скатерть из плотной ткани и на ней оставляют традиционные угощения для Хозяина Алтая.

После начинается подготовка ритуальных лент дьалама / кыйра, традиционными цветами являются белый, голубой, зеленый и желтый. Готовые ленты проводят над пламенем, объясняя это тем, что необходимо убрать все торчащие нитки. Первым повязывает алкышчы, потом остальные участники, во время подвязывания люди просят благословления, здоровья и благополучия себе и своим близким.

Подвязав дьалама все, участники идут обратно к тагылам и рассаживаются. После этого алкышчы молоком из ритуальной деревянной пиалы начинает окроплять огонь и таким образом приступает к ритуалу благословения огня на тагылах (по алтайским поверьям - дочери Солнца). С этого ритуала начинаются все обряды. Алкышчы начинает моление с обращения духу огня От-Эне, сопровождая молитвы кормлением молоком и возжиганием можжевельника, в ходе молитв он совместно с помощником преподносит духу огня принесенные продукты, сжигая их в огне. Моления продолжаются восхвалением Алтая, алкышчы обращается к Хозяину Алтая, перечисляет все большие сакральные горы Алтая, священные местности и горные массивы, перевалы, прося здоровья народу, плодородия для скота. Моления сопровождаются кроплением молоком по сторонам света, прося достатка в семьях, мягкой зимы и теплого лета. Вслед за ним все присутствующие поклоняются духу огня От-Эне, проговаривая молитвы, прошения про себя.

По завершению молитв-прошений, проводимых алкышчы, присутствующие сами производят кормление огня молоком, сопровождая кропления благопожеланиями алкыш`ами.

Участники молений по завершению ритуальной части спускаются в стан, и там устраивается трапеза (едят мясо, перловый суп кёчё).

В Кош-Агачском районе обряд поклонения Алтаю во время осенних молений Сары бюр проводился по той же схеме, как и во время весенних молений Дьажылбюр (см. выше)

Заключение. Таким образом, все обряды содержали вполне объяснимые значительные внешние отличия друг от друга. Однако, сравнив составляющие всех вариантов обряда поклонения Алтаю у разных алтайских этнических групп, можно прийти к выводу, что наблюдаемые различия проявляются в основном на уровне текста благопожеланий и некоторых (впрочем, тоже важных) внешних элементов обряда, что связано с различием локальных традиций. Глубинная же семантика, направленность обряда и основные его этапы идентичны, что позволяет отнести все описанные обряды к одной общей алтайской традиции.

Также полагаем, что собранные материалы в ходе полевых работ могут послужить основой для дальнейшего изучения обрядового фрольклора алтайцев, анализа современного состояния обрядовой сферы жизни алтайцев, где можно проследить трансформацию традиционных обрядов в наши дни.

Практические результаты могут быть использованы при написании учебников и учебных пособий по фольклору и этнографии алтайцев в современный период, а также в работах фрольклористов, этнографов, преподавателей высших, средних учебных заведений, аспирантов, магистрантов, студентов. 


\section{Әдебиеттертізімі / Список литературы}

1. Арзютов, 2014 - Арзютов Д.В. Алтайский ритуальный ковер и создание гетеротопии // Антропологический фрорум. 2014. №18. - С. 85-133. [Электронный ресурс] / URL: http://anthropologie.kunstkamera.ru/files/pdf/018online/arzutov.pdf (дата обращения 21.05.2019]

2. Вербицкий, 1893 - Вербицкий В.И. Алтайские инородцы. М., 1893. - 256 с.

3. Календарные обряды // Большая российская энциклопедия. Том 12. Москва: Издательство «БРЭ», 2008. - 767 c.

4. Календарные обычаи и обряды народов Восточной Азии. Новый год. / Ред. Б.Л. Модель М.: Гл. ред. вост. лит.изд-ва «Наука», 1985.

\section{References}

Arzyutov, 2014 - Arzyutov D.V. Altajskij ritual'nyj kover i sozdanie geterotopii // Antropologicheskij forum. 2014. №18. - S. 85-133. [Elektronnyj resurs] / URL: http://anthropologie.kunstkamera.ru/ files/pdf/018online/arzutov.pdf (data obrashcheniya 21.05.2019] [In Rus.].

Verbickij, 1893 - Verbickij V.I. Altajskieinorodcy.M., 1893. - 256 s. [In Rus.]

Kalendarnye obryady // Bol'shaya rossijskaya enciklopediya. Tom 12. Moskva: Izdatel'stvo «BRE», 2008. - 767 s. [In Rus.].

Kalendarnye obychai i obryady narodov Vostochnoj Azii. Novyj god. / Red. B. L. Model' M.: Gl. red. vost. lit.izd-va «Nauka», 1985 [In Rus.]. 